\title{
Identification and determination of characteristics of endophytes from rice plants and their role in biocontrol of bacterial blight caused by Xanthomonas oryzae pv. oryzae
}

\author{
H. Yousefi', N. Hassanzadeh ${ }^{1 *}$, K. Behboudi² and F. Beiki Firouzjahi ${ }^{3}$
}

Summary Endophytic bacteria of rice plants (Oryza sativa L.) from eight different cultivars were screened for their ability in inducing disease symptoms, plant growth promotion and antagonistic activity against Xanthomonas oryzae pv. oryzae. Out of the 63 whole isolates, five were plant pathogens. Based on phenotypic characteristics and $16 \mathrm{~S}$ rDNA sequence analysis, these were identified as Pseudomonas oryzihabitans, P. fulva, Pantoea ananatis, Pantoea sp., Cellulomonas sp. Four out of the 63 isolates behaved as potentially good plant growth-promoting and biocontrol agents. These were identified as Bacillus sp., B. subtilis, Pseudomonas putida and Enterobacter sp. This is the first report of pathogenic and endophytic bacteria from rice grown in field conditions in North of Iran.

Additional keywords: endophytic bacteria, Oryza sativa L., plant pathogens, PGPR, 16S rRNA gene

\section{Introduction}

Beneficial endophytic microorganisms are primarily comprised of fungi and bacteria that colonize internal plant tissues without causing visible damage to their hosts. (Schulz and Boyle, 2006; Rodriguez et al., 2008; Rodriguez et al., 2009; Reinhold-Hurek and Hurek, 2011). These local and systemic colonizers of the internal tissue can be isolated from sterile surface or internal parts of plants (Hallmann et al., 1997) from both monocotyledonous and dicotyledonous plants (Ryan et al., 2008).

Endophytes enter the plant through the natural vents and wounds, or by secretion of hydrolytic enzymes (Hallmann et al., 1997). They subsequently establish closer interaction with the host by increasing access to nutrients such as nitrogen, phosphorus and iron, or by inducing plant defense mechanisms (production of anti-pathogen agents,

1 Department of Plant Pathology, Faculty of Agricultural Sciences and Food Industries, Science and Research Branch, Islamic Azad University, Tehran, Iran.

2 Department of Plant Protection, University College of Agriculture and Natural Resources, University of Tehran, Karaj 31587-77871, Iran.

${ }^{3}$ Iranian Research Institute of Plant Protection (IRIPP), Research Department of Biological Control, P.O. Box 59, Amol, Iran.

* Corresponding author: hasanzadehr@yahoo.com suppression of pathogens through competition for the colonization of places and food) and can potentially positively affect plant health and protection (Kang et al., 2007; Reinhold-Hurek and Hurek, 2011; Santoyo et al., 2016; Moronta-Barrios et al., 2017).

Several reports have highlighted the benefits of using endophytic bacteria as biocontrol agents against fungal and bacterial rice pathogens. Burkholderia sp. KJ006, for example, was used against Burkholderia glumae (Cho et al., 2007) and Rhizobium leguminosarum bv. phaseoli against Rhizoctonia solani (Mishra et al., 2006). Similarly, other endophytic bacteria have been used to protect rice cultivars from major fungal infections including Penibacillus spp., Microbacterium spp., Bacillus spp. and Klebsiella spp. against Fusarium oxysporum and Rhizoctonia solani (Ji et al., 2014). Recently certain potential biological control agents such as Bacillus amyloliquefaciens, $B$. methylotrophicus and $B$. subtilis were isolated from rice plants showing the highest antimicrobial activities against the two major rice pathogens, Rhizoctonia solani and Burkholderia glumae, which cause sheath blight and bacterial panicle blight, respectively (Shrestha et al., 2016). For these and other reasons, nowadays endophytes are increasingly receiving attention as potential agents in the biologi- 
cal control of plant pathogens as well as for the improvement of plant growth.

Rice is the staple food of more than half of the world's population. It is considered the oldest and the most important crop throughout the world, especially in Asia. Considerable agricultural areas are under cultivation of rice in the world.

Bacterial blight caused by Xanthomonas oryzae pv. oryzae (Xoo) is a devastating pathogen in rice, especially in Asian countries. It reduces rice production by $20 \%$ in natural conditions and by $70 \%$ in epidemic situations, being one of the factors that limit the global production of rice $(\mathrm{Ou}, 1985)$. For the control of the pathogen, plant disease resistance (R) genes are used to generate new disease-resistant cultivars (Peng et al., 2015) and isolation of potent endophytes as new sources for biological control of plant pathogens is under investigation.

The aim of the present study was to isolate and identify certain endophytic bacteria from commonly used rice cultivars in northern Iran, in order to evaluate their effect as biocontrol agents against rice bacterial blight caused by Xoo.

\section{Materials and methods}

\section{Isolation of endophytic bacteria from rice plants}

Samples were collected from eight rice cultivars cultivated in regions under rice plantation in the north of Iran. They were washed with tap water to separate soil particles from the root surface. Disinfection followed by using $2 \%$ hypochlorite sodium for 10 minutes and $70 \%$ alcohol for 1 minute. The plant samples were then rinsed four times with $0.02 \mathrm{M}$ phosphate potassium buffer $(\mathrm{pH}=7)$. To ensure the effectiveness of disinfectants, a $0.1 \mathrm{ml}$ buffer from the final wash was added to $9.9 \mathrm{ml}$ Tryptic soy agar (TSA) as control. Any growth in the control plates within 48 hours, these were eliminated. The root, stem and leaf samples were then cut into small pieces via a sterile blade. One gram of sample tissue with $9.9 \mathrm{ml}$ phos- phate buffer was squashed in a sterile mortar. The solution was diluted serially in the buffer and cultured on a TSA medium in a Petri dish. Single colonies were selected and purified on fresh TSA plates (Mclnroy and Kloepper, 1995).

\section{Preliminary diagnosis of bacterial patho- genic isolates}

To determine the pathogenic properties of 63 isolates, appropriate suspensions of yellow colonies and fluorescent bacteria were prepared and the inocula were infiltrated into tobacco leaves to fulfill HR development. To confirm pathogenicity tests on rice plants cv. Hashemi, two pathogenicity tests were conducted simultaneously (Zou et al., 2006; Shrestha et al., 2016; Jabeen et al., 2011).

In the first experiment, the leaves were cut off and surface-sterilized with sodium hypochlorite solution for 1 minute and then washed with $\mathrm{dd}_{2} \mathrm{O}$. The sterilized leaves were then placed on a three-layer paper towel in Petri dishes and inoculated with suspensions of representative isolates with $10^{8} \mathrm{cfu} /$ $\mathrm{ml}$ concentration using the pin prick method. All treated leaves including water treated control leaves were inoculated at $25^{\circ} \mathrm{C}$. The test was conducted in three replications for each treatment.

In the second experiment, one-monthold rice plants were inoculated with bacteria at a concentration of $10^{8} \mathrm{cfu} / \mathrm{ml}$ from fresh cultures by the leaf-clipping method (Kauffman et al., 1973). The treated plants were transferred to the greenhouse at $25-30^{\circ} \mathrm{C}$ with a 12- hr exposure period. They were observed every day within one month for any disease symptoms. The control plants were inoculated with sterile phosphate buffer. Experiments were performed in three replicates for each treatment.

\section{Phenotypic characteristics of the patho- genic isolates}

Pathogenic isolates were studied by a series of key phenotypic tests, including physiological and biochemical tests, in terms of the determination of genus and species 
(Schaad et al., 2001).

\section{In vitro assay for antagonistic properties of isolates}

To carry out the tests for antagonistic properties of isolates, Xoo-strain (MT) was used. From a 24-48 hour culture of the strain on a TSA medium, a suspension was prepared in sterile distilled water and its optical density $\left(O D_{600}\right)$ was adjusted 1 . Isolates with colonies other than yellow colours, all positive fluorescent bacteria and saprophytes with no HR reaction, were spot-inocuated on TSA medium and incubated for three days at $25^{\circ} \mathrm{C}$. Then, Xoo suspension at $10^{8}$ $\mathrm{cfu} / \mathrm{ml}$ concentration was sprayed uniformly on TSA agar medium. The plates were incubated at $25^{\circ} \mathrm{C}$, and inhibition zones were measured. This was done in triplicates.

\section{Germination and vigour index of inocu-} lated rice seeds with endophytic bacteria

The test was conducted on the basis of the standard method of roll towel (ISTA, 1993). At first, 20 surface sterilized seeds were treated in $3 \times 10^{8} \mathrm{cfu} / \mathrm{ml}$ concentration of each isolate and each batch was placed separately between two plies of a wet tissue and the seeds were a slightly compressed. The tissues containing the treated seeds were then placed separately in plastic bags which were rolled and kept in a growth chamber for 14 days. Three replications were considered for each treatment. The percentage of seed germination, and the mean root and shoot length of each seedling were indices evaluated for the growth-inducing activity of isolates. To calculate the vigour index of the seedling, the following method was used (Baki and Anderson, 1973):

Vigour index $=\%$ germination $\times$ seedling length

Seedling length $=$ (shoot length + root length)

\section{Evaluation of plant growth promotion of endophytic bacteria on rice in green- house conditions}

An assessment of the growth improve- ment activity of 17 selected isolates from the Vigour index test was done according to Chithrashree et al. (2011). Seeds treated with fresh suspensions of antagonistic isolates $\left(3 \times 10^{8} \mathrm{cfu} / \mathrm{ml}\right)$ and untreated control seeds were separately planted in pots filled with sterile soil and sand in equal volumes. The pots were irrigated daily and each pot received $25 \mathrm{ml}$ of Hoagland 1/3 (V/V) solution once a week. Within 30 days after planting, the plant's growth promotion activities such as plant height and fresh weight of seedlings were measured. Each treatment consisted of four replicates (Chithrashree et al., 2011).

\section{Evaluation of the effect of endophyt- ic-antagonistic bacteria against Xoo in greenhouse conditions}

The rice seeds were kept in sterile distilled water for 48 hours after surface disinfection with $2 \%$ hypochlorite sodium for 30 seconds. Then, the extra water of the seeds was removed and air-dried in the shade for half an hour. Six seeds were planted in vases containing sterile soil. Each cellular suspension of antagonistic bacteria was used separately in greenhouse during plantation. The one-month plants with suspension of XoO $\left(10^{8} \mathrm{cells} / \mathrm{ml}\right)$ were inoculated using the leaf clipping method (Kauffman et al., 1973). The test was done in the form of a complete random design in three replications. The control plants were inoculated with sterile distilled water. The length of lesions on leaves of each plant was measured separately after 45 days of inoculation with the pathogen, based on a five-point scale: $0=$ no sign of diseases and lesion length less than 0.2 $\mathrm{cm}, 1=$ lesion length between 0.2 and 1.5 $\mathrm{cm}, 3=$ lesion length between 1.5 and $3 \mathrm{~cm}$, $5=$ between 3 and $5 \mathrm{~cm}, 7=$ between 5 and $10 \mathrm{~cm}, 9=$ above $10 \mathrm{~cm}$. The percentage disease index was calculated by the following formula (Fang et al., 1999):

Disease index $(\%)=\left\{\left(1 \times N_{1}+3 \times N_{3}+5 \times N_{5}+7\right.\right.$ $\left.\left.\times \mathrm{N}_{7}+9 \times \mathrm{N}_{9}\right) / 9 \mathrm{Nt}\right\} \times 100$

where $\mathrm{N}_{1-9}$ is the number of the leaf index and $\mathrm{Nt}$ is the total number of tested leaves. 
In this test, growth factors such as fresh weight of root and shoots were measured.

\section{Bacterial identification using 16S rRNA gene sequencing}

\section{DNA Extraction}

To extract DNA of isolates, the boiling method was used. Bacterial cultures were obtained in $5 \mathrm{ml}$ Nutrient broth (Nb) medium. After keeping it in $37^{\circ} \mathrm{C}$ incubator for 20 hours, $1 \mathrm{ml}$ from each culture was transfered into sterile Eppendorf tube, and centrifuged in $13000 \mathrm{rpm}$ for 5 minutes. The supernatants were discharged and pellets were resuspended by vortexing with $300 \mu \mathrm{l}$ lysis buffer containing $0.1 \mathrm{~N} \mathrm{NaOH}$ and $0.5 \%$ SDS (Elboutahiri et al., 2009). The tubes were placed in a boiling bain-marie for 10-13 minutes and immediately were placed on the ice for one minute. The tubes were centrifuged in $13000 \mathrm{rpm}$ for 5 minutes and the supernatants contain suspended DNA was transferred into new tubes for PCR reaction.

\section{PCR amplification}

The amplification of 165 rDNA was carried out in a reaction with a final volume of $25 \mu \mathrm{l}$ containing $2.5 \mu \mathrm{l}$ of $10 \times$ PCR buffer, $1 \mu \mathrm{l}$ of $\mathrm{MgCl}_{2}, 0.5 \mu$ l of dNTP (2.5 mM) (Bio-Rad), 1 $\mu \mathrm{l}(100 \mathrm{ng} / \mu \mathrm{l})$ of the P1 primer (5'-CGGGATCCAGAGTTTGATCCTGGTCAGAACGAACGCT $\left.-3^{\prime}\right), 1 \mu \mathrm{l}(100 \mathrm{ng} / \mu \mathrm{l})$ of the P6 primer (5'-CGGGATCCTACGGCTACCTTGTTACGACTTCACCCC -3') (Palacio-Bielsa et al. 2009), $0.3 \mu \mathrm{l}$ of Taq DNA polymerase, $2 \mu \mathrm{l}$ of total DNA and $16.7 \mu \mathrm{l}$ of sterile distilled $\mathrm{H}_{2} \mathrm{O}$. The PCR reaction conditions were as follows: $94^{\circ} \mathrm{C}$ for 2 min, followed by 25 cycles of denaturation at $94^{\circ} \mathrm{C}$ for $1 \mathrm{~min}$, annealing at $52^{\circ} \mathrm{C}$ for 1 min and extension at $72^{\circ} \mathrm{C}$ for $3 \mathrm{~min}$, before a final elongation at $72^{\circ} \mathrm{C}$ for $20 \mathrm{~min}$.

\section{Statistical analysis}

The results of the experiments were analyzed independently. The treatment means were compared by Duncan's multiple range test. The statistical software SAS version 92.1 was used for the statistical analyses.

\section{Results}

Isolation, identification and characterization of endophytic bacteria

Sixty three (63) culturable bacterial endophytes were isolated from internal tissues of the rice plants collected from different parts of North of Iran. Yellow and fluorescent colonies HR positive were tested for HR and pathogenicity tests on rice plants ( $\mathrm{Ta}$ ble 1).

\section{Pathogenicity test}

Of the 63 endophytic bacterial isolates, 6 isolates had positive $\mathrm{HR}$ reaction on tobacco leaves. Five isolates namely, OS6, OS14, OS18, OS22 and OS36, caused disease symptoms on inoculated rice plants. Some of these were considered as pathogens with low disease potential. All pathogenic strains in the detached leaf assay showed a typical elongated water soaked lesion which developed into a brownish black necrosis. These were recorded 48-72 $\mathrm{h}$ post-inoculation (hpi). In the pot experiment all plants inoculated with pathogenic endophyte strains showed progressive water-soaking lesions in the inoculated point after 2-4 days. The lesions became necrotic and produced a necrotic stripe on the leaf that spread to the full length of the leaf. The isolates with low disease potential produced confined dark brown spots on the inoculated region. Koch's postulates were fulfilled for all pathogenic strains.

\section{Phenotypic properties of the pathogen- ic isolates}

The tested endophytes isolates were divided into two groups; yellow colonies up to fluorescent pigmentation on king's B medium and the non-fluorescent, and the white colonies group. As presented in Table 2, five strains were tentatively identified based on morphological and various biochemical characteristics. Two of the strains namely, OS6 and OS36, were designated as Pseudomonas spp. Two other strains (OS14 and OS18) were identified as Pantoea spp., and the strain OS22 could not be assigned 
Table 1. Overall characteristics of endophytic bacteria isolated from rice cultivars.

\begin{tabular}{l|c|c|c|c}
\hline Cultivar & Tissue origin & $\begin{array}{c}\text { Pathogenicity } \\
\text { in rice }\end{array}$ & Strain number & Colony color on TSA \\
\hline Hashemi & $10^{-3}$ Leaf & -- & OS4, OS18 & yellow \\
& $10^{-4}$ Leaf & ++- & OS6, OS14, OS46 & yellow \\
& $10^{-5}$ Leaf & -- & OS15, OS16 & yellow \\
Tarom amrollahi & $10^{-3}$ Root & - & OS2, OS19 & yellow \\
& $10^{-5}$ Leaf & - & OS7 & colorless \\
Kouhsar & $10^{-6}$ Leaf & - & OS17 & yellow \\
& $10^{-2}$ Leaf & + & OS22 & yellow \\
& $10^{-4}$ Leaf & - & OS38 & yellow \\
Binam & $10^{-2}$ Root & - & OS20 & colorless \\
& $10^{-3}$ Leaf & + & OS36 & yellow \\
& $10^{-4}$ Leaf & - & OS25 & yellow \\
Amol & $10^{-2}$ Root & - & OS28 & white \\
& $10^{-4}$ Root & - & OS49 & creamy \\
& $10^{-2}$ Stem & - & OS31 & yellow \\
Fajr & $10^{-2}$ Root & - & OS29 & yellow \\
Khazar & $10^{-3}$ Root & - & OS30 & yellow \\
& $10^{-3}$ Root & -- & OS32, OS34 & yellow \\
Tarom hashemi & $10^{-4}$ Leaf & - & OS33 & yellow \\
& $10^{-3}$ Root & - & OS42 & brown \\
Tarom mahalli & $10^{-3}$ Root & - & OS43 & colorless \\
& $10^{-3}$ Root & - & OS53 & yellow \\
& $10^{-3}$ Leaf & - & OS60 & yellow \\
& $10^{-4}$ Root & -- & OS61, OS62 & yellow \\
\hline
\end{tabular}

Table 2. The phenotypic characteristics of five main endophytic bacteria with low disease potential isolated from rice plants.

\begin{tabular}{l|c|c|c|c|c}
\hline Test & OS6 & OS14 & OS18 & OS22 & OS36 \\
\hline Yellow pigment & + & + & + & + & + \\
Gram staining & - & - & - & + & - \\
Oxidase test & - & - & - & + & - \\
Fermentative & No & Yes & Yes & No & No \\
Fluorescence on King's B medium & - & - & - & - & - \\
Starch hydrolysis & - & - & - & - & - \\
Catalase hydrolysis & + & + & + & + & + \\
Litmus milk & ALK & ND & ND & - & ALK \\
Levan from sucrose & + & - & - & - & + \\
$\mathrm{H}_{2} S$ from cysteine & - & - & - & - & - \\
Xanthomondin & - & - & - & - & - \\
Mucoid growth on YDC & + & + & + & + & - \\
Growth on 0.1\% TTC & - & + & + & + & + \\
Growth at $40^{\circ} \mathrm{C}$ & + & + & + & & - \\
HR on Tobacco & + & + & + & + & + \\
Pathogenicity on rice & + & + & + & + \\
\hline
\end{tabular}

$+=$ positive; ${ }^{-}=$negative; $\mathrm{O}=$ oxidative; $\mathrm{v}=$ variable; $\mathrm{ALK}=$ alkaline; $\mathrm{NC}=$ no change; $\mathrm{ND}=$ not determined. 
to a known species (Table 2).

In vitro assay for antagonistic activities of isolates to $X$. oryzae pv. oryzae

In the initial screening of the antagonistic activity of 39 bacterial isolates against Xoo strain, 21 bacterial isolates exhibited the most potent antagonistic activity against the Xoo. The maximum inhibitory activity was recorded for OS59 with an inhibition zone of $32.67 \mathrm{~mm}$, whereas the isolates OS58, OS43, OS20 and OS40 could produce inhibition zones of $32.33 \mathrm{~mm}, 26.65 \mathrm{~mm}, 18$ $\mathrm{mm}$ and $16.7 \mathrm{~mm}$, respectively (Fig.1). The selected isolates were consequently used for further experimentation.

Germination and vigour index of inoculated rice seeds with endophytic bacteria

In total, 17 bacterial strains selected from the in vitro assays, namely, OS3, OS10, OS12, OS20, OS21, OS23, OS28, OS31, OS40, OS43, OS44, OS49, OS52, OS53, OS55, OS58 and OS59, were tested. The treatment of seeds with some of these strains significantly increased the seed germination and seedling vigour in comparison to the untreated control. Of these, 6 isolates namely, OS40, OS23, OS43, OS52, OS31 and OS53, had statistically significant effects compared to the control (Table 3). Further tests were carried out to evaluate their potential in promoting plant growth.

\section{Effect of endophytic bacteria on growth promotion of rice in greenhouse condi- tions}

Under greenhouse conditions, of the 17 isolates tested, $41.176 \%$ of the isolates caused a significant difference in growth parameters compared to the control plants. Seed treatments with OS3, OS23, OS31, OS40, OS53, OS58 and OS59 isolates increased seedling height and fresh weight in comparison with the control. The highest heights of $23.7,22.81,21.9 \mathrm{~cm}$ were obtained from seeds treated with the OS58, OS40 and OS31 isolates. The application of the OS53, OS31, and OS59 isolates also resulted in the highest seedling weights of $0.893,0.806$ and 0.6662 grams (Fig. 2).

Evaluation of the effect of endophytic-antagonistic bacteria against XoO in greenhouse condition

Seventeen (17) representative antagonistic bacteria with potential plant growth promotion activities were assessed for the control of bacterial blight disease 60 days after the treatment of rice seeds with endophytic bacteria. As shown in Fig. 3, the plants with bacterial inoculants of OS52, OS40, OS23 and OS53, reduced the incidence of the disease by $28.5 \%, 33.25 \%, 34.25 \%$ and $37.25 \%$, respectively (Fig. 3). Also in presence of the pathogen $X_{0 o}$, root and shoot fresh weight of the rice plants inoculated with the mentioned isolates showed significantly increased values of these parameters compared to the control treatment (Fig. 4). This indicates their function as biological control agents of XOO causing bacterial blight in rice.

\section{PCR test for identification of representa- tive bacteria}

To identify the four most efficient antagonistic endophytes (OS52, OS40, OS23 and OS53), the extracted DNA of these isolates were amplified using universal $16 \mathrm{~S}$ rDNA primers ( $\mathrm{P} 1$ and $\mathrm{P} 6$ ) and a PCR product size of 1500 bp was obtained. The sequencing samples were sent to Macrogene Inc. (Seoul, South Korea). The sequence results were compared with those available in the NCBI GenBank. It was shown that the isolates OS23, OS40, OS52 and OS53 with 97\%, $90 \%, 95 \%$ and $98 \%$ identities belonged to Bacillus sp., B. subtilis, Enterobacter sp. and Pseudomonas putida, respectively (Fig. 5). However, 2 species were indistinguishable by $16 S$ rRNA gene sequences.

\section{Discussion}

Eight cultivars of rice were screened for beneficial endophytic bacteria in the provinces of Mazandaran and Gilan in northern Iran during two seasons in the year 2016. Sixty three endophytes were isolated from differ- 


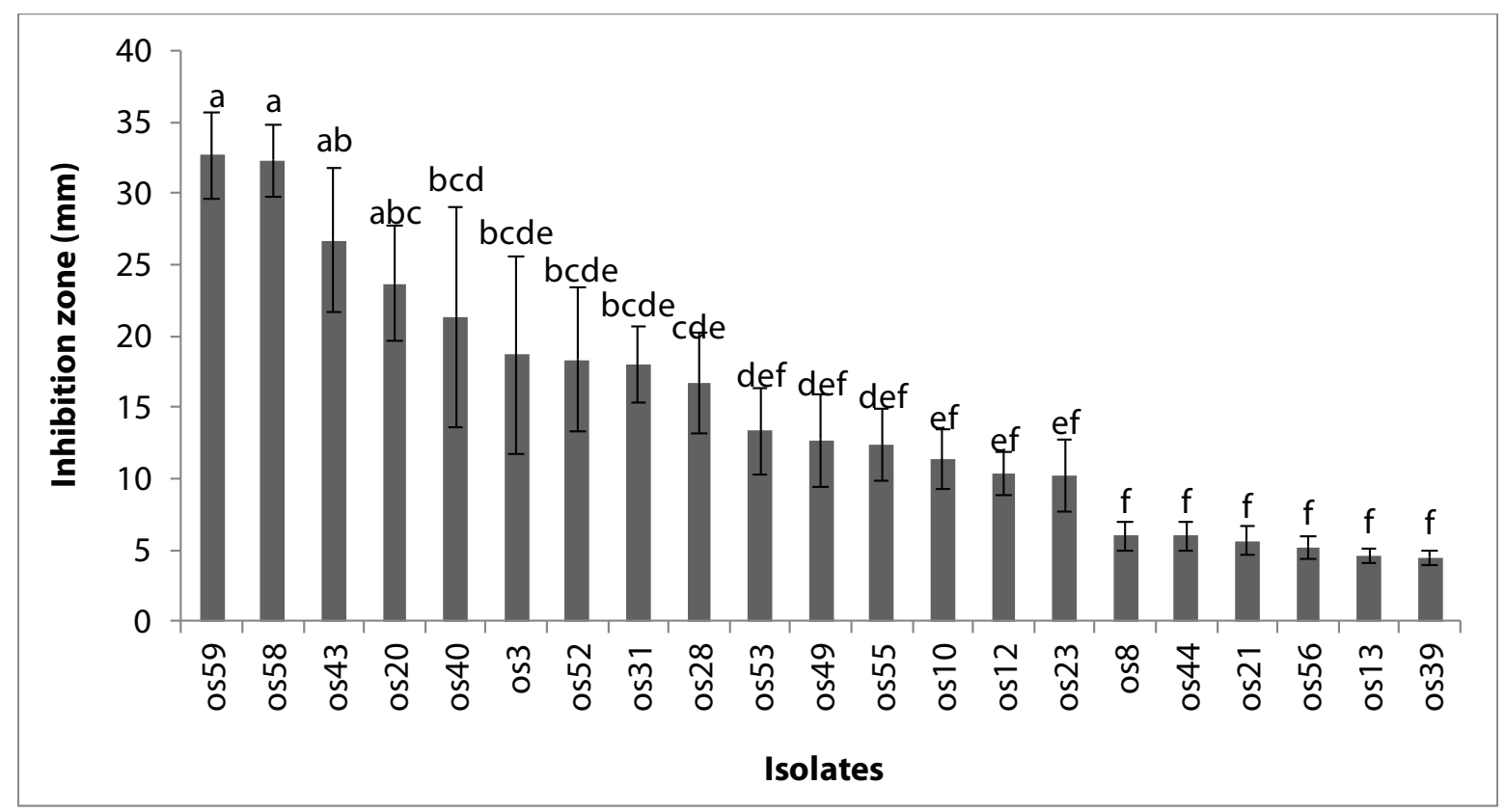

Figure 1. Comparative antagonistic potential of 21 endophytic bacteria against Xanthomonas oryzae pv. oryzae in rice. *Data are mean of three replications; in a column, means followed by a common letter are not significantly different at $5 \%$ level by Duncan's Multiple Range Test.

Table 3. Plant growth promoting activity of endophytic bacterial isolates in rice plants.

\begin{tabular}{c|c|c|c|c}
\hline Isolates & MRL $(\mathrm{cm})$ & $\mathrm{MSL}(\mathrm{cm})$ & Germination $(\%)$ & $\mathrm{Vl}^{*}$ \\
\hline OS3 & $2.72 \pm 0.60^{\mathrm{bcd}}$ & $5.57 \pm 0.51^{\mathrm{ef}}$ & 100 & $8.16 \pm 0.44^{\mathrm{fg}}$ \\
OS10 & $2.59 \pm 0.13^{\mathrm{cde}}$ & $4.69 \pm 0.45^{\mathrm{g}}$ & 96 & $7.12 \pm 1.00^{\mathrm{h}}$ \\
OS12 & $2.40 \pm 0.26^{\mathrm{de}}$ & $5.78 \pm 0.62^{\mathrm{cdef}}$ & 98 & $8.01 \pm 0.77^{\mathrm{fgh}}$ \\
OS20 & $3.12 \pm 0.21^{\mathrm{b}}$ & $5.41 \pm 0.25^{\mathrm{f}}$ & 100 & $7.55 \pm 0.22^{\mathrm{gh}}$ \\
OS21 & $2.17 \pm 0.40^{\mathrm{de}}$ & $4.00 \pm 0.27^{\mathrm{gh}}$ & 100 & $4.90 \pm 0.36^{\mathrm{i}}$ \\
OS23 & $4.19 \pm 0.32^{\mathrm{a}}$ & $6.45 \pm 0.47^{\mathrm{abcd}}$ & 100 & $11.01 \pm 0.77^{\mathrm{ab}}$ \\
OS28 & $2.4067 \pm 0.1^{\mathrm{de}}$ & $3.37 \pm 0.21^{\mathrm{h}}$ & 94 & $5.43 \pm 0.21^{\mathrm{i}}$ \\
OS31 & $2.52 \pm 0.12^{\mathrm{de}}$ & $6.18 \pm 0.13^{\mathrm{abcde}}$ & 100 & $9.64 \pm 0.32^{\mathrm{bcd}}$ \\
OS40 & $4.31 \pm 0.25^{\mathrm{a}}$ & $6.51 \pm 0.58^{\mathrm{abc}}$ & 100 & $11.28 \pm 0.56^{\mathrm{a}}$ \\
OS43 & $4.01 \pm 0.10^{\mathrm{a}}$ & $6.73 \pm 0.39^{\mathrm{a}}$ & 100 & $10.51 \pm 0.38^{\mathrm{ab}}$ \\
OS44 & $2.03 \pm 0.17^{\mathrm{e}}$ & $3.63 \pm 0.27^{\mathrm{h}}$ & 96 & $5.43 \pm 0.44^{\mathrm{i}}$ \\
OS49 & $2.56 \pm 0.16^{\mathrm{cde}}$ & $6.13 \pm 0.25^{\mathrm{abcdef}}$ & 100 & $8.66 \pm 0.11^{\text {def }}$ \\
OS52 & $4.03 \pm 0.25^{\mathrm{a}}$ & $5.95 \pm 0.58^{\mathrm{bcdef}}$ & 100 & $10.03 \pm 0.18^{\mathrm{bc}}$ \\
OS53 & $3.15 \pm 0.37^{\mathrm{b}}$ & $6.64 \pm 0.41^{\mathrm{ab}}$ & 100 & $9.45 \pm 0.66^{\mathrm{cd}}$ \\
OS55 & $3.07 \pm 0.26^{\mathrm{bc}}$ & $6.57 \pm 0.53^{\mathrm{ab}}$ & 100 & $9.20 \pm 0.27^{\mathrm{cde}}$ \\
OS58 & $3.82 \pm 0.26^{\mathrm{a}}$ & $5.70 \pm 0.40^{\text {def }}$ & 100 & $7.78 \pm 0.42^{\mathrm{fgh}}$ \\
OS59 & $2.55 \pm 0.40^{\mathrm{cde}}$ & $5.40 \pm 0.35^{\mathrm{f}}$ & 100 & $8.36 \pm 0.94^{\mathrm{efg}}$ \\
Co & $2.02 \pm 0.33^{\mathrm{e}}$ & $4.00 \pm 0.21^{\mathrm{gh}}$ & 100 & $5.65 \pm 0.64^{\mathrm{i}}$ \\
\hline
\end{tabular}

$M R L=$ Mean root length, $M S L=$ Mean shoot length, $\mathrm{VI}=$ Vigour Index .

* Data are mean of three replications; in a column, means followed by a common letter are not significantly different at $5 \%$ level by Duncan's Multiple Range Test. 


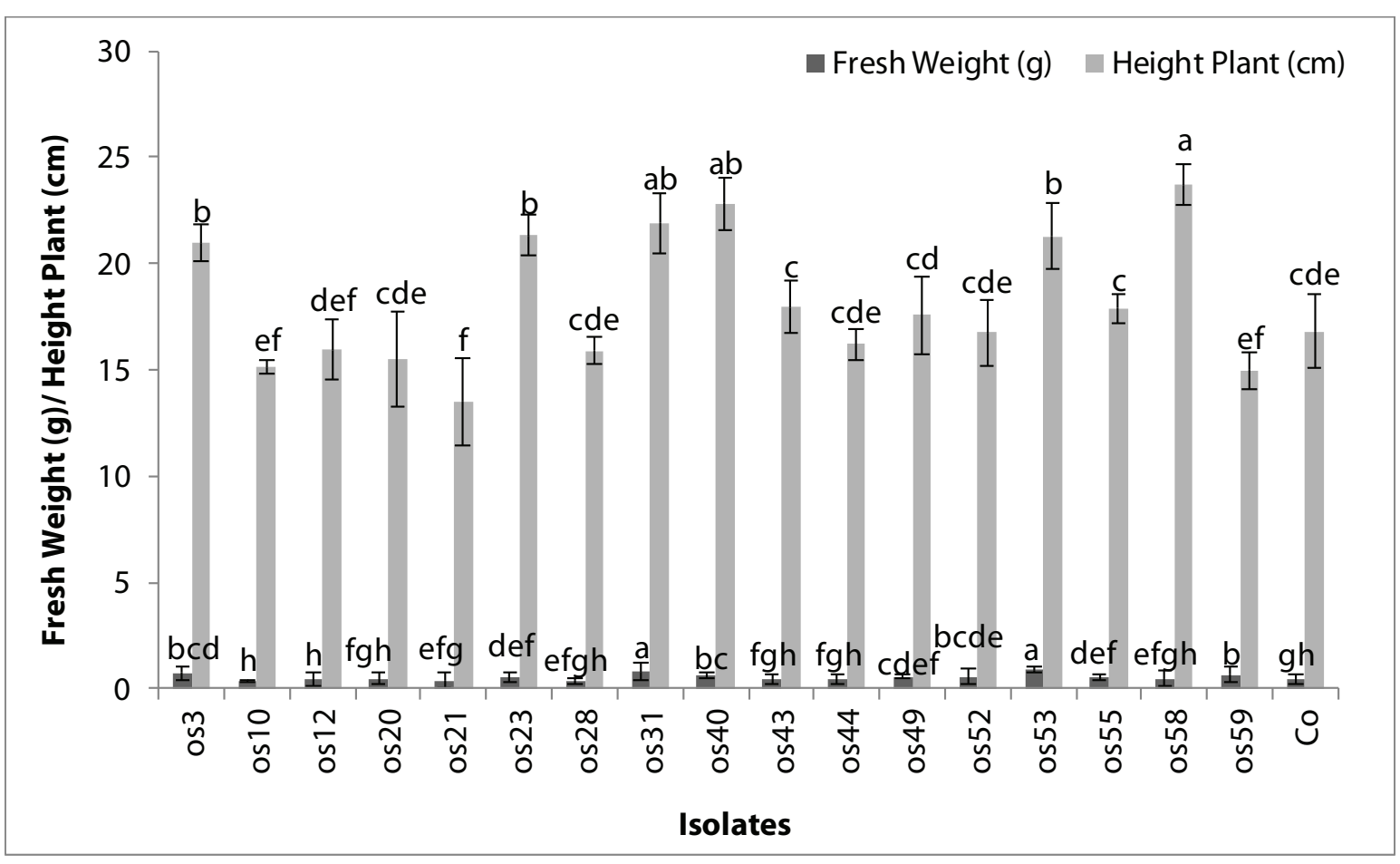

Figure 2. Effect of endophytic bacteria on growth promotion of rice seedlings 30 days after application in greenhouse conditions.

*Data are mean of four replications; in a column, means followed by a common letter are not significantly different at $5 \%$ level by Duncan's Multiple Range Test.



Figure 3. Control of bacterial blight of rice by endophytic bacteria under greenhouse conditions 60 days after treatment. *Data are mean of four replications; in a column, means followed by a common letter are not significantly different at $5 \%$ level by Duncan's Multiple Range Test. 


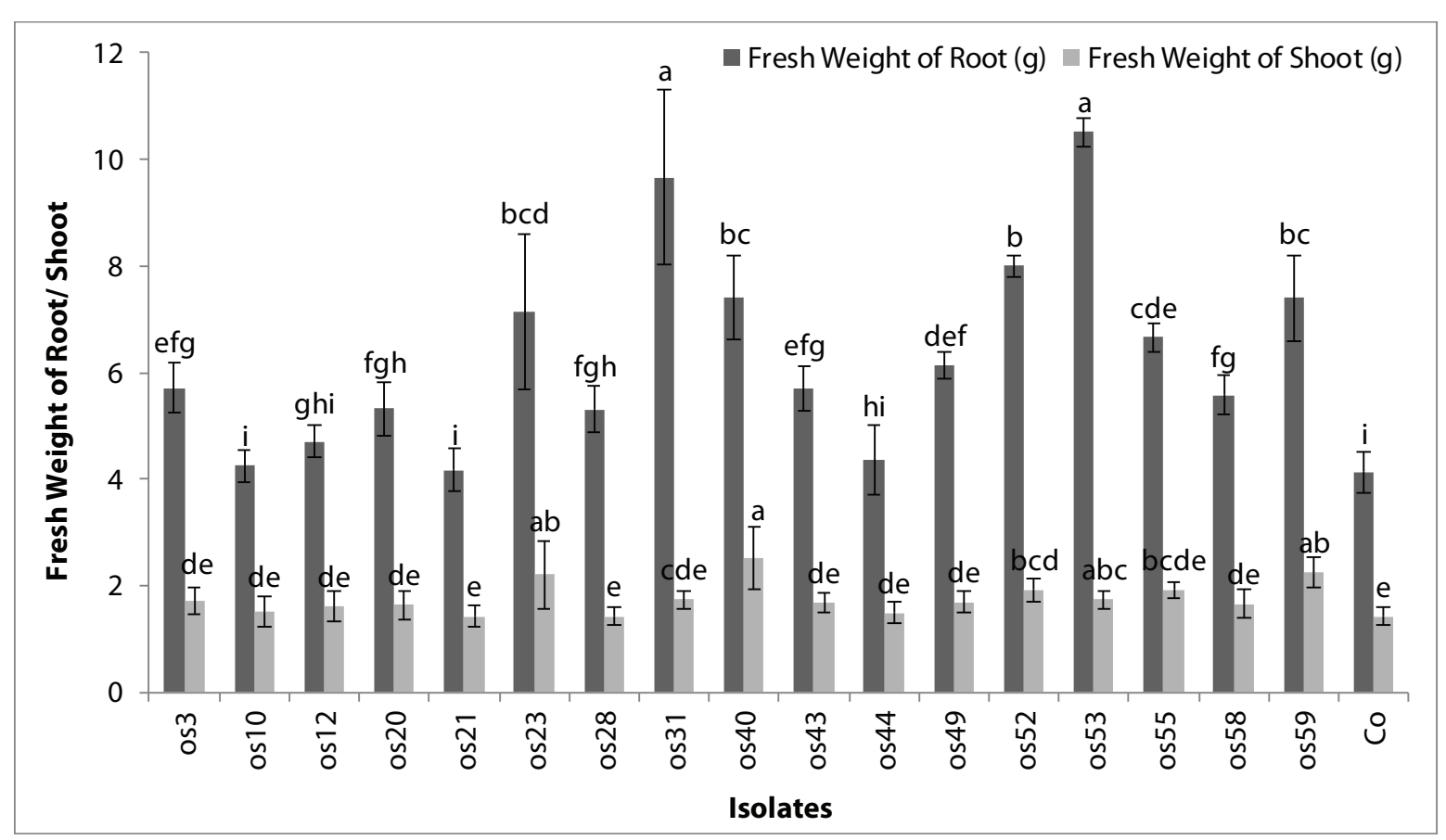

Figure 4. Different plant growth promoting activity of the representative endophytic bacteria on rice in greenhouse conditions and in presence of the pathogen Xanthomonas oryzae pv. oryzae in rice.

*Data are mean of four replications; in a column, means followed by a common letter are not significantly different at $5 \%$ level by Duncan's Multiple Range Test.

ent parts of the plants including the leaves, stem and roots.

Based on pathogenicity tests, five of the isolates were considered as potential pathogens of rice, which after $16 \mathrm{~s}$ rDNA sequencing were identified as Pseudomonas oryzihabitans (99\%), Pantoea ananatis (96\%), Pantoea sp. (96\%), Cellulomonas sp. (97\%) and Pseudomonas fulva (97\%). It is worth mentioning that neither of these bacteria have been previously reported as rice pathogens in Iran. The remaining isolates were considered non-pathogenic isolates.

Of the pathogenic isolates found on rice, some have already been reported on rice plants. Pantoea ananatis from Cambodia, and Pantoea spp. and Pantoea stewartii from the Philippines have been identified as pathogens with different pathogenic potential (Cother et al., 2010; Mano et al., 2006; Mano et al., 2007; Okunishi et al., 2005; Cottyn et al., 2001; Cottyn et al., 2009). Pseudomonas oryzihabitans, Pseudomonas spp. and Cellulomonas flavigena have been reported as seed saprophytes in irrigated areas with low pathogen- ic potential trait from the Philippines (Cottyn et al., 2001; Cottyn et al., 2009). Moreover, Pseudomonas fulva has been identified as a pathogen in pepper from China and as a diazotrophic endophyte in rice seeds (Qiang et al., 2017; Verma et al., 2001).

According to Cottyn et al. (2009), it can be assumed that under certain conditions of rice cultivation, these endophytes can eventually appear as pathogens. Generally, some endophytes may turn into pathogens depending on several factors such as: the host and endophyte growth stage, plant defensive responses, environmental changes such as $\mathrm{CO}_{2}$ accumulation or $\mathrm{O}_{2}$ depletion, the production of specific metabolites in another host, the presence of other microorganisms interacting with it (Lund and Wyatt, 1972; van Peer et al., 1990; Sturz et al., 1997; Schulz and Boyle, 2005; Rosenblueth and Martínez-Romero, 2006). Nevertheless, in artificial inoculation, factors such as inoculation procedure and high inoculum concentrations may increase pathogenicity (Cottyn et al., 2009). 


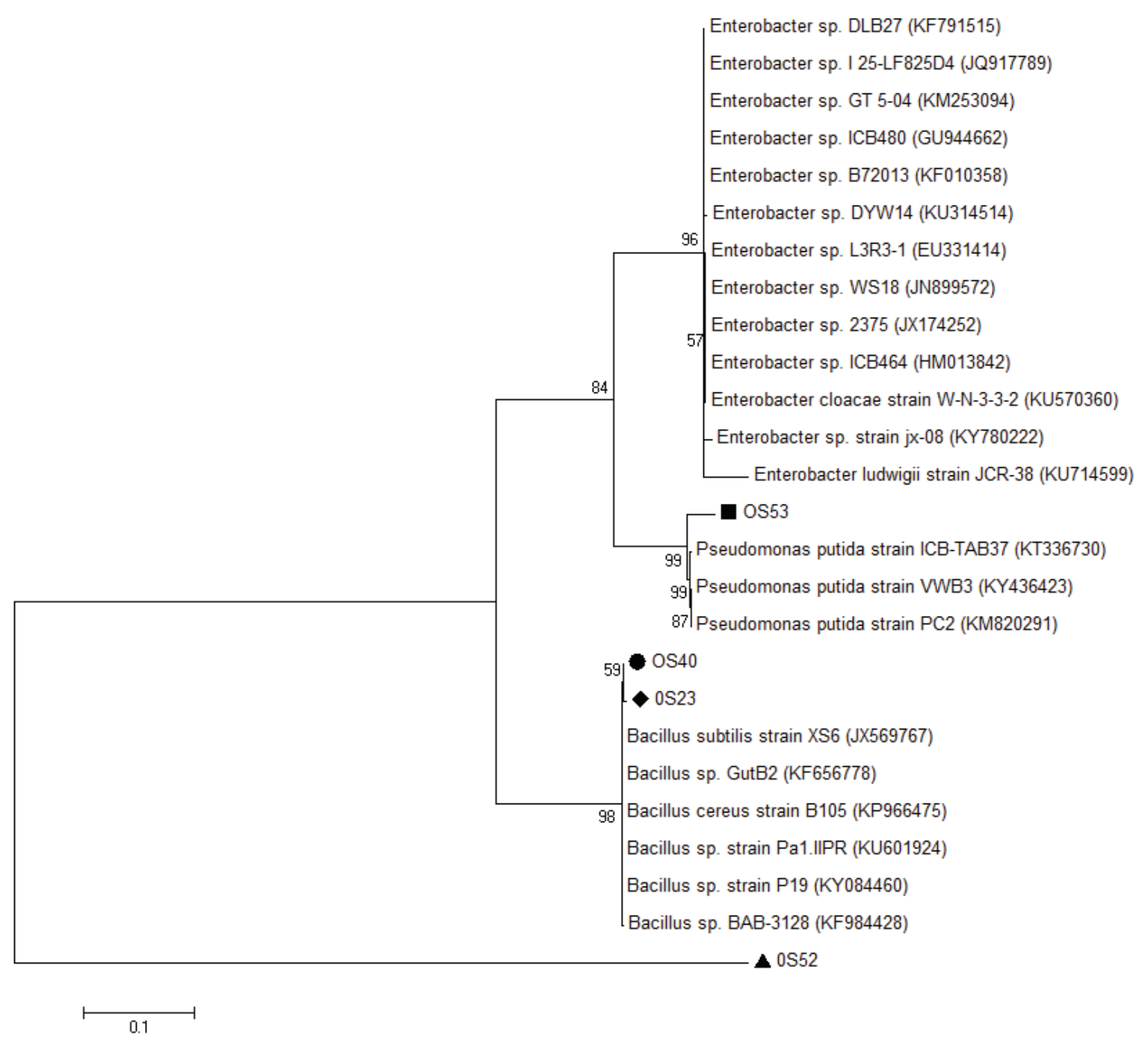

Figure 5. Phylogenetic tree based on the 165 rRNA gene of 4 beneficial endophytic bacteria and related bacterial species. The evolutionary history was inferred by using the Maximum Likelihood method based on the Kimura 2-parameter model. The numbers at the nodes are boot strap values based on 1000 replications. The analysis involved 26 nucleotide sequences. Evolutionary analyses were conducted in MEG 7 (Tamura et al., 2013; Kumar et al., 2016).

To select the best antagonists, screening of isolates was based on their in vitro antagonistic activity to Xoo, their effect on seed germination rate, seedling growth promotion and the reduction of disease intensity in greenhouse conditions. Four isolates, OS52, OS40, OS23 and OS53, which were identified by nucleotide sequence analysis as Enterobacter sp., B. subtilis, Bacillus sp. and Pseudomonas putida, respectively, could increase plant growth and decrease Xoo infection under greenhouse conditions. To the best of our knowledge, this is the first report of isolation of endophytes from rice in Iran. Seed treatment with these antagonists caused disease to cease in over $60 \%$ of plants. These species have been found as endophytes in rice among many other species including Coryneform spp., Pantoea spp., Burkholderia glumae, Xanthomonas spp., Staphylococcus spp., Paenibacillus polymyxa, Methylobacterium spp., Curtobacterium spp., Azospirillum amazonense, Caulobacter crescentus, Kocuria palustris, Micrococcus luteus, Microbacterium spp., Klebsiella spp., Azospirillum spp., Herbaspirillum spp., Rhizobium spp., Sphingomonas spp. and Brevibacillus spp. (Elbeltagy et al., 2000; Okunishi et al., 2005; Mano et 
al., 2007; Mano and Morisaki, 2008; Cottyn et al., 2009; Kaga et al., 2009; Ji et al., 2014; Nhu and Diep, 2014).

Several endophytic bacteria such as Enterobacter sp. CNPSo 2480, Bacillus sp. CNPSo 2481, Pseudomonas rhodesiae, Pantoea ananatis, Pseudomonas sp. PsJN, H. rubrisubalbicans, G. diazotrophicus, A.amazonense and Burkholderia sp. induce growth and increase in plants like corn, pepper, grape and sugarcane (Barka et al., 2002; Oliveira et al., 2003; Kang et al., 2007; Szilagyi-Zecchin et al., 2014). In addition, endophytic bacteria have been reported to be involved with other mechanisms such as competition for place and food, and antibiosis (Sturz et al., 2000; Reiter et al., 2002; Compant et al., 2005; Aravind et al., 2009; Ji et al., 2013). Especially in rice, Ji et al. (2013) found that treatment of rice seeds with the diazotrophic endophytes Paenibacillus, Microbacterium, Bacillus and Klebsiella, induced systemic resistance against Fusarium oxysporum and Rhizoctonia solani in addition to the growth induction of the rice plant.

In the present study, B. subtilis seemed to work well against $X o O$ as well as the other Bacillus spp., which need to be investigated further. Recent studies by Chung et al. (2015) and Hossain et al. (2016) showed that Bacillus oryzicolaYC7007, a new endophytic bacterium isolated from rice roots, improves plant growth and controls bacterial blight, cluster blight and bakanae disease via the production of antibiotic and induction of systemic resistance. The application of an endophytic strain Bacillus spp. of tomato and potato with Silwet polysilicon surfactant caused colonization of cocoa leaves (for more than 68 days) and reduction of black pod rot disease via the induction of systemic resistance (Melnick et al., 2008).

The Enterobacter sp. isolate also has a potential beneficial effect on the control of bacterial blight. Of Enterobacter spp., Enterobacter radicincitans in cereals (Witzel et al., 2012), Enterobacter sp. SP1 in sugar cane (Zhu et al., 2012) and Enterobacter cloacae MSR1 in alfalfa (Khalifa et al., 2016) have shown an ability to increase production in plants. The production of plant hormones by the Enterobacter sp. 638 isolated from the stem of a type of poplar hybrid has led to a $40 \%$ increase in poplar growth (Taghavi et al., 2010). Enterobacter cloacae and Enterobacter aerogenes strains have been reported to control Fusarium oxysporum f. sp. spinaciae in spinach (Tsuda et al., 2001) and Setosphaeria turcica, the Northern corn leaf blight fungus, in maize (D'Alessandro et al., 2014). Biological control action of $E$. cloacae has also been reported by Roberts et al. (1994). Enterobacter isolates increased nodule occupancy of bradyrhizobial strains at nitrogen fixation on legumes (Gulpa et al., 1998).

The increase in the growth of rice plants by the activity of $P$. putida coincides with previous findings on endophytic Pseudomonas spp. e.g. nitrogen fixation by Pseudomonas stuzeri A1501 endophyte promoted plant growth (Yan et al., 2008). Sheoran et al. (2015) proved that the endophytic P. putida BP25, isolated from the black pepper root endosphere, could by internal colonization in Ginger and Arabidopsis plants induce production of volatile compounds that inhibit fungal pathogens and the plant parasitic nematode Radopholus similis (Sheoran et al., 2015).

Despite the interesting profile of Enterobacter sp. and P. putida as antagonists of Xoo on rice, these bacteria are potentially dangerous and harmful to human health (Brenner et al., 1986; Bouallegue et al., 2004; Berg et al., 2005; Flores-Tena et al., 2007; Molina et al., 2011; Thomas et al., 2013; Molina et al., 2014). Hence the hazardous properties of the bacteria and human safety issues should also be taken into account when considering their practical use as biological control agents in plant protection.

In conclusion, this is the first record of the pathogens $P$. oryzihabitans, $P$. ananatis, Pantoea sp., Cellulomonas sp. and P. ful$v a$ and the endophytic bacteria/ antagonists Enterobacter sp., B. subtilis, Bacillus sp. and $P$. putida against $X o o$ in rice plants from the northern parts of Iran, where rice is mostly cultivated. The beneficial bacteria showed promising efficacy and plant growth pro- 
motion activities against $X_{0 o}$ in rice both in vitro and in greenhouse conditions. Further research is required in the perspective of application of the present findings to the field.

\section{Literature Cited}

Aravind, R., Kumar, A., Eapen, S.J. and Ramana K.V. 2009. Endophytic bacterial flora in root and stem tissues of black pepper (Piper nigrum L.) genotype: isolation, identification and evaluation against Phytophthora capsici. Letters in Applied Microbiology, 48: 58-64.

Baki, A.A.A. and Anderson, J.D. 1973. Vigour determination in soybean seed by multiple criteria. Crop Science, 31: 630-633.Barka, E. A., Gognies, S., Nowak, J., Audran, J. C. and Belarbi, A. 2002. Inhibitory effect of endophytic bacteria on Botrytis cinerea and its influence to promote the grape vine growth. Biological Control, 24: 135-142.

Berg, G., Eberl, L. and Hartmann, A. 2005. The rhizosphere as a reservoir for opportunistic human pathogenic bacteria. Environmental Microbiology, 7(11): 1673-1685.

Bouallegue, O., Mzoughi, R., Weill, F. X., Mahdhaoui, N., Ben Salem, Y., Sboui, H., Grimont, F. and Grimont, P.A. 2004. Outbreak of Pseudomonas putida bacteraemia in a neonatal intensive care unit. The Journal of Hospital Infection, 57(1): 88-91.

Brenner, D.J., Mcwhorter, A.C., Kai, A., Steiger Walt, A.G. and Farmer, J.J. 1986. Enterobacter asburiae sp-nov, a new species found in clinical specimens, and reassignment of Erwinia dissolvens and Erwinia nimipressuralis to the genus Enterobacter as Enterobacter dissolvens comb-nov and Enterobacter nimipressuralis comb-nov. Journal of Clinical Microbiology, 23(6): 1114-1120.

Chithrashree-Udayashankar, A.C., Chandra-Nayaka, S., Reddy, M.S. and Srinivas C. 2011. Plant growth-promoting rhizobacteria mediate induced systemic resistance in rice against bacterial leaf blight caused by Xanthomonas oryzae pv. oryzae. Biological Control, 59: 114-122.

Cho, H.S., Park, S.Y., Ryu, C.M., Kim, J.F., Kim, J.G. and Park, S.H. 2007. Interference of quorum sensing and virulence of the rice pathogen Burkholderia glumae by an engineered endophytic bacterium. Microbial Ecology, 60: 14-23.

Chung, E.J., Hossain, M.T., Khan, A., Kim, K.H., Jeon, C.O. and Chung, Y.R. 2015. Bacillus oryzicola sp. nov., an endophytic bacterium isolated from the root of rice with anti-microbial, plantgrowth promoting and systemic resistance-inducing activities in rice. The Plant Pathology Journal, 31: 152-164.

Compant, S., Duffy, B., Nowak, J., Cle'ment, CH. and
Ait Bark, E. 2005. Use of Plant Growth-Promoting Bacteria for Biocontrol of Plant Diseases: Principles, Mechanisms of Action, and Future Prospects. Applied and Environmental Microbiology, 71(9): 4951-4959.

Cother, E.J., Noble, D.H., van de Ven, R.J., Lanoiselet, V., Ash, G., Vuthy, N., Visarto, P. and Stodart, B. 2010. Bacterial pathogens of rice in the Kingdom of Cambodia and description of a new pathogen causing a serious sheath rot disease. Plant Pathology, 59: 944-953.

Cottyn, B., Regalado, E., Lanoot, B., De Cleene, M., Mew, T.W. and Swings, J. 2001. Bacterial Populations Associated with Rice Seed in the Tropical Environment. Phytopathology, 91(3): 282-292.

Cottyn, B., Debode, J., Regalado, E., Mew, T.W. and Swings, J. 2009. Phenotypic and genetic diversity of rice seed-associated bacteria and their role in pathogenicity and biological control. Journal of Applied Microbiology, 107:885-897.

D'Alessandro, M., Erb, M., Ton, J., Brandenburg, A., Karlen, D., Zopfi, J. and Turlings, T.C.J. 2014. Volatiles produced by soil-borne endophytic bacteria increase plant pathogen resistance and affect tritrophic interactions. Plant, Cell and Environment, 37(4): 813-826.

Elbeltagy, A., Nishioka, K., Suzuki, H., Sato, T., Sato, Y.I., Morisaki, H., Mitsui, H. and Minamisawa, K. 2000. Isolation and characterization of endophytic bacteria from wild and traditionally cultivated rice Varieties. Soil Science and Plant Nutrition, 46(3): 617-629.

Elboutahiri, N., Thami-Alami, I., Zaïd, E. and M.Udupa, S. 2009. Genotypic characterization of indigenous Sinorhizobium meliloti and Rhizobium sullae by rep-PCR, RAPD and ARDRA analyses. African Journal of Biotechnology, 8 (6): 979-985.

Fang, Z.D., Xu, Z.G., Guo, C.J., Yin, S.Z., Wu, S.Z., Xu, X.M. and Zhang, Q. 1990. Studies on pathotypes of Xanthomonas campestris pv. oryzae in China. Acta Phytopathologica Sinica, 20: 81-88.

Flores-Tena, F.J., Guerrero-Barrera, A.L., AvelarGonzález, F.J., Ramírez-López, E.M., and Martínez-Saldaña, M.C. 2007. Pathogenic and opportunistic gram-negative bacteria in soil, leachate and air in San Nicolás landfill at Aguascalientes, México. Revista Latinoamericana de Microbiología, 49: 25-30.

Gupta, A., Saxena, A. K., Gopal, M. and Tilak, K. V. B. R. 1998. Effect of plant growth promoting rhizobacteria on competitive ability of introduced Bradyrhizobium sp. (Vigna) for nodulation. Microbiol Res, 153:113-117.

Hallmann, J., Quadt-Hallmann, A., Mahaffee, W.F. and Kleopper, W. 1997. Bacterial endophytes in agricultural crops. Canadian Journal of Microbiology, 43: 895-914.

Hossain, M.T., Khan, A., Chung, E.J., Harun-Or Rashid, Md. and Chung, Y.R. 2016. Biological Control of 
Rice Bakanae by an Endophytic Bacillus oryzicola YC7007. The Plant Pathology Journal, 32(3): 228-241.

ISTA. 1993. Proceedings of the international Seed Testing Association, International Rules for Seed Testing. Seed Science and Technology, 21: 25-30.

Jabeen, R., Iftikhar, T., Ashraf, M. and Ahmad, I. 2011. Virulence/ aggressiveness testing of Xanthomonas oryzae pv. oryza isolates causes BLB disease in rice cultivars of Pakistan. Pakistan Journal of Botany, 43(3): 1725-1728.

Ji, S.H., Gururani, M.A. and Chun, S.Ch. 2014. Isolation and characterization of plant growth promoting endophytic diazotrophic bacteria from Korean rice cultivars. Microbiological Research, 169: 83-98.

Kaga, H., Mano, H., Tanaka, F., Watanabe, A., Kaneko, S. and Morisaki, H. 2009. Rice Seeds as Sources of Endophytic Bacteria. Microbes and Environments, 24(2): 154-162.

Kang, S.H., Cho, H.S., Cheong, H., Ryu, C.M., Kim, J.F. and Park, S.H. 2007. Two bacterial endophytes eliciting both plant growth promotion and plant defense on Pepper (Capsicum annuum L.). Journal of Microbiology and Biotechnology, 17(1): 96-103.

Kauffman, H.E., Reddy, A.P.K., Hsieh, S.P.Y. and Merca, S.D. 1973. An improved technique for evaluating resistance of rice varieties to Xanthomonas oryzae. Plant Disease Reporter, 57: 537-541.

Khalifa, A.Y.Z., Alsyeeh, A.M., Almalki, M.A. and Saleh, F.A. 2016. Characterization of the plant growth promoting bacterium, Enterobacter cloacae MSR1, isolated from roots of non-nodulating Medicago sativa. Saudi Journal of Biological Sciences, 23: 79-86.

Kumar, S., Stecher, G. and Tamura, K. 2016. MEGA7: Molecular Evolutionary Genetics Analysis version 7.0 for bigger datasets. Molecular Biology and Evolution, 33: 1870-1874.

Lund, B.M. and Wyatt, G.M. 1972. The effect of oxygen and carbon dioxide concentrations on bacterial soft rot of potatoes. I. King Edward potatoes inoculated with Erwinia carotovora var. atroseptica. Potato Research, 15: 174-179.

Mano, H., Tanaka, F., Watanabe, A., Kaga, H., Okunishi, S. and Morisaki, H. 2006. Culturable surface and endophytic bacterial flora of the maturing seeds of rice plants (Oryza sativa) cultivated in a paddy field. Microbes and Environments, 21: 86100.

Mano, H., Tanaka, F., Nakamura, C.H., Kaga, H. and Morisaki, H. 2007. Culturable endophytic bacterial flora of the maturing leaves and roots of rice plants (Oryza sativa) cultivated in a paddy field. Microbes and Environments, 22 (2): 175-185.

Mano, H. and Morisaki, H. 2008. Endophytic Bacteria in the Rice Plant. Microbes and Environments, 23(2): 109-117.
McInroy, J.A. and Kloepper, J.W. 1995. Population dynamics of endophytic bacteria in field- grown sweet corn and cotton. Canadian Journal of Microbiology, 41: 895-901.

Melnick, R.L., Zidack, N.K., Bailey, B.A., Maximova, S.N., Guiltinan, M., Backman, P.A. 2008. Bacterial endophytes: Bacillus spp. from annual crops as potential biological control agents of black pod rot of cacao. Biological Control, 46: 46-56. doi:10.1016/j.biocontrol.2008.01.022.

Mishra, R.P., Singh, R.K., Jaiswal, H.K., Kumar, V. and Maurya, S. 2006. Rhizobium-mediated induction of phenolics and plant growth promotion in rice (Oryza sativa L.). Current Microbiology 52 (5): 383-9.

Molina, L., Duque, E., Gómez, M.J., Krell, T., Lacal, J., García-Puente, A., García, V., Matilla, M.A., Ramos, J.L. and Segura, A. 2011. The pGRT1 plasmid of Pseudomonas putida DOT-T1E encodes functions relevant for survival under harsh conditions in the environment. Environmental Microbiology, 13(8): 2315-27.

Molina, L., Udaondo, Z., Duque, E., Fernández, M., Molina-Santiago, C., Roca, A., Porcel, M., de la Torre, J., Segura, A., Plesiat, P., Jeannot, K. and Ramos, J.L. 2014. Antibiotic resistance determinants in a Pseudomonas putida strain isolated from a hospital. PLOS ONE, 9(1): e81604. doi: 10.1371/journal.pone.0081604.

Moronta-Barrios, F., Gionechetti, F., Pallavicini, A., Marys, E. and Venturi, V. 2017. Isolation and studies on bacterial endophytes from two venezuelan rice cultivars. Preprints (www.preprints.org). doi:10.20944/preprints201709.0031.v1

Nhu, V.T.P. and Diep, C.N. 2014. Isolation, characterization and phylogenetic analysis of endophytic bacteria in rice plant cultivated on soil of Phu Yen province, Vietnam. American Journal of Life Sciences, 2(3): 117-127.

Okunishi, S., Sako, K., Mano, H., Imamura, A. and Morisaki, H. 2005. Bacterial Flora of Endophytes in the Maturing Seed of Cultivated Rice (Oryza sativa). Microbes and Environments, 20(3): 168177.

Oliveira, A.L.M., Canuto, E.L., Reis, V.M. and Baldani, J.I. 2003. Response of micropropagated sugarcane varieties to inoculation with endophytic diazotrophic bacteria. Brazilian Journal of Microbiology, 34: 59-61.

Ou, S.H. 1985. Rice Diseases. $2^{\text {nd }}$ ed. Kew- SurreyEngland: Common Wealth Mycological Institute, $380 \mathrm{p}$.

Palacio-Bielsa, A., Cambra, M.A. and López, M.M. 2009. PCR detection and identification of plantpathogenic bacteria: updated review of protocols (1989-2007). Journal of Plant Pathology, 91 (2): 249-297.

Peng, H., Chen, Z. H., Fang, Z. H., Zhou, J., Xi, Z. H., Gao, L., Chen, L., Li, L., Li, T., Zhai, W. and Zhang, 
W. 2015. Rice Xa21 primed genes and pathways that are critical for combating bacterial blight infection. Scientific Reports, 5: 12165. doi: 10.1038/srep12165.

Roberts, D. P., Short, N. M., Maloney, A. P., Nelson, E. B. and Schaff, D. A. 1994. Role of colonization in biocontrol: studies with Enterobacter cloacae. Plant Science, 101: 83-89.

Qiang, SH., Ming, L., Jingjing, G., Xianglin, Zh. and Chunzhu, Zh. 2017. Characterization of Pseudomonas fulva as a new pathogen of pepper leaf spot isolated from Xinjiang in China. Journal of Plant Protection, 2.

Reinhold-Hurek, B. and Hurek, T. 2011. Living inside plants: bacterial endophytes. Curren Opinion in Plant Biology, 14: 435-443.

Reiter, B., Pfeifer, U., Schwab, H. and Sessitsch, A. 2002. Response of endophytic bacterial communities in potato plants to infection with $E r$ winia carotovora sub sp. atroseptica. Applied and Environmental Microbiology, 68: 2261-2268.

Rodriguez, R.J., Henson, J., Van Volkenburgh, E., Hoy, M., Wright, L., Beckwith, F., Kim, Y.O. and Redman, R.S. 2008. Stress tolerance in plants via habitat-adapted symbiosis. The ISME Journal, 2(4): 404-16.

Rodriguez, R.J., White, J.F.Jr., Arnold, A.E., Redman, R.S. 2009. Fungal endophytes: diversity and functional roles. New Phytologist, 182 (2): 31430.

Rosenblueth, M. and Martínez-Romero, E. 2006. Bacterial Endophytes and Their Interactions with Hosts. Molecular Plant-Microbe Interactions, 19 (8): 827-837.

Ryan, R.P., Germaine, K., Franks, A., Ryan, D.J. and Dowling, D.N. 2008. Bacterial endophytes: recent developments and applications. FEMS Microbiology Letters, 278 (1): 1-9.

Santoyo, G., Moreno-Hagelsieb, G., Orozco-Mosqueda, M.C. and Glick, B.R. 2016. Plant growth-promoting bacterial endophytes. Microbiological Research, 183: 92-99.

Schaad, N.W., Jones, J. B. and Chun, W. 2001. Laboratory guide for identification of plant pathogenic bacteria. $3^{\text {rd }}$ ed. St Paul Minnesota- USA: APS, 245 p.

Schulz, B. and Boyle, C. 2005. The endophytic continuum. Mycological Research, 109: 661-686.

Schulz, B., Boyle, C. 2006. What are endophytes? In: Schulz, B.J.E., Boyle, C.J.C., Sieber, T.N. (eds). Microbial Root Endophytes. Berlin, Germany, Springer, pp 1-13.

Sessitsch, A., Reiter, B. and Berg, G. 2004. Endophytic bacterial communities of field-grown potato plants and their plant-growth-promoting and antagonistic abilities. Canadian Journal of Microbiology, 53: 239-249.

Sheoran, N., Nadakkakathb, A, V., Munjal, V., Kundu,
A., Subaharand, K., Venugopal, V., Rajamma, S., Eapen., S. J. and Kumara, A. 2015. Genetic analysis of plant endophytic Pseudomonas putida BP25 and chemo-profiling of its antimicrobial volatile organic compounds. Microbiological Research, 173: 66-78.

Shrestha, B.K., Karki, H.S., Groth, D.E., Jungkhun, N. and Ham, J.H. 2016. Biological control activities of rice-associated Bacillus sp. strains against sheath blight and bacterial panicle blight of rice. PLOS ONE, 11(1): e0146764. doi:10.1371/ journal.pone.0146764.

Sturz, A.V., Christie, B.R., Matheson, B.G., and Nowak, J. 1997. Biodiversity of endophytic bacteria which colonize red clover nodules, roots, stems and foliage and their influence on host growth. Biology and Fertility of Soils, 25: 13-19.

Sturz, A.V., Christie, B.R. and Nowak, J. 2000. Bacterial endophytes: potential role in developing sustainable system of crop production. Critical Reviews in Plant Sciences, 19: 1-30.

Szilagyi-Zecchin, V.J., Ikeda, A.C., Hungria, M., Adamoski, D., Kava-Cordeiro, V., Glienke, C.H. and Galli-Terasawa, L.V. 2014. Identification and characterization of endophytic bacteria from corn (Zea mays L.) roots with biotechnological potential in agriculture. AMB Express, 4: 26.

Taghavi, S., Van der Lelie, D., Hoffman, A., Zhang, Y-B., Walla, M.D., Vangronsveld, J., Newman, L. and Monchy, S. 2010. Genome Sequence of the Plant Growth Promoting Endophytic Bacterium Enterobacter sp. 638. PLoS Genetics, 6(5): e1000943. doi:10.1371/journal.pgen.1000943.

Tamura, K., Stecher, G., Peterson, D., Filipski, A. and Kumar, S. 2013. MEGA6: Molecular Evolutionary Genetics Analysis version 6.0. Molecular Biology and Evolution, 30: 2725-2729.

Thomas, B.S., Okamoto, K., Bankowski, M.J. and Seto, T.B. 2013. A lethal case of Pseudomonas putida bacteremia due to soft tissue infection. Infectious Diseases in Clinical Practice, 21(3): 147-213.

Tsuda, K., Kosaka, Y., Tsuge, S., Kubo, Y. and Horino, O. 2001. Evaluation of the endophyte Enterobacter cloacae SM10 isolated from spinach roots for biological control against Fusarium wilt of spinach. Journal of General Plant Pathology, 67: 78-84.

van Peer, R., Punte, H.L.M., de Weger, L.A. and Schippers, B. 1990. Characterization of root surface and endorhizosphere pseudomonads in relation to their colonization of roots. Applied and Environmental Microbiology, 56: 2462-2470.

Verma, S.C., Ladha, J.K. and Tripathi, A.K. 2001. Evaluation of plant growth promoting and colonization ability of endophytic diazotrophs from deep water rice. Journal of Biotechnology, 91: 127-141.

Witzel, K., Gwinn-Giglio, M., Nadendla, S., Shefchek, K. and Ruppel, S. 2012. Genome sequence of 
enterobacter radicincitans DSM16656T, a plant growth-promoting endophyte. Journal of Bacteriology, 194 (19): p. 5469.

Zhu, B., Chen, M., Lin, L., Yang, L., Li, Y. and An, Q. 2012. Genome sequence of Enterobacter sp. strain SP1, an endophytic nitrogen-fixing bacterium isolated from sugarcane. Journal of Bacteriology, 194 (24): p. 6963-6964.

Zou, L.F., Wang, X.P., Xiang, Y., Zhang, B., Li, Y.R., Xiao, Y.L., Wang, J.Sh., R. Walmsley, A. and Chen, G. You. 2006. Elucidation of the hrp clusters of Xanthomonas oryzae pv. oryzicola that control the hypersensitive response in nonhost tobacco and pathogenicity in susceptible host rice.
Applied and Environmental Microbiology, 72: 6212-6224.

Yang, J.H., Liu, H.X., Zhu, G.M., Pan, Y.L., Xu, L.P. and Guo, J.H. 2008. Diversity analysis of antagonists from rice-associated bacteria and their application in biocontrol of rice diseases. Journal of Applied Microbiology, 104: 91-104.

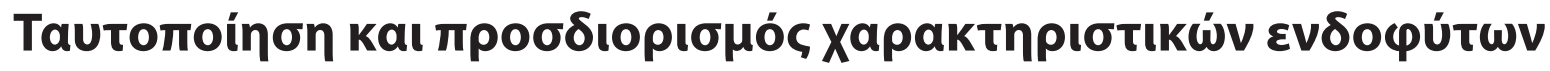

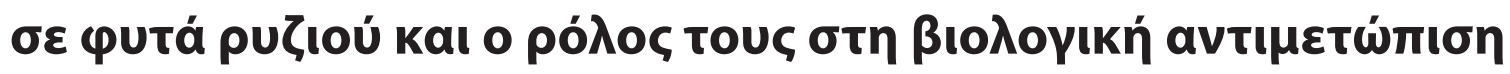 tou ßaktnpiou Xanthomonas oryzae pv. oryzae
}

\author{
H. Yousefi, N. Hassanzadeh, K. Behboudi kaı F. Beiki Firouzjahi
}

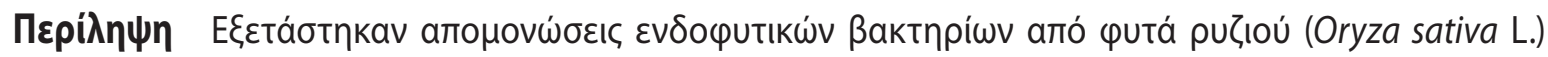

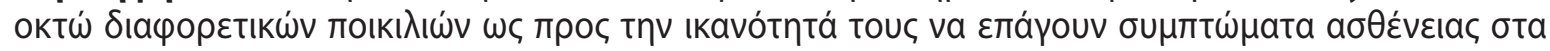

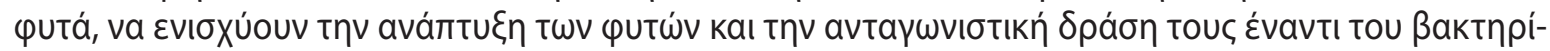

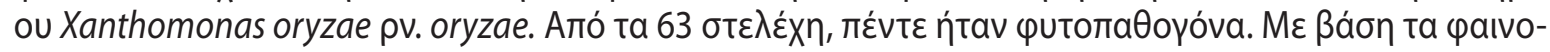

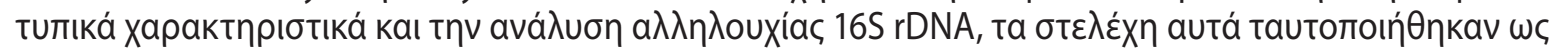

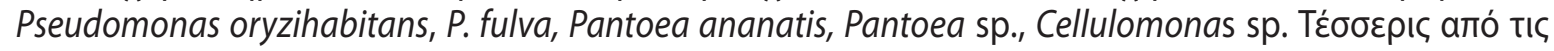

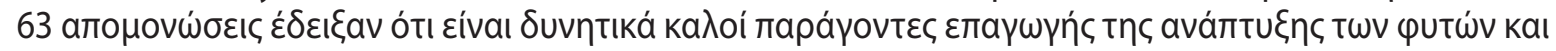

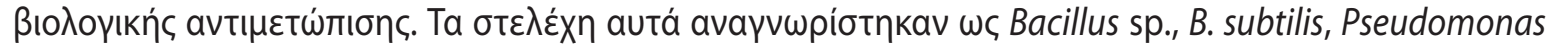

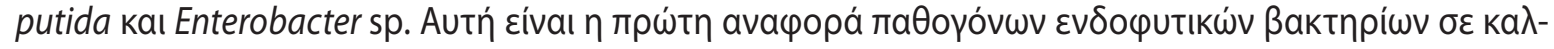



